\title{
Preovulatory LH characteristics and time of ovulation in the prolific Booroola Merino ewe
}

\author{
B. M. Bindon, L. R. Piper and J. Thimonier* \\ CSIRO, Division of Animal Production, Armidale, New South Wales 2350, Australia
}

\begin{abstract}
Summary. In 4 separate experiments involving 133 ewes the timing of the onset of the LH discharge relative to the onset of oestrus was compared in prolific Booroola Merinos and in other Merinos of low (' $\mathrm{C}$ ' and ' $\mathrm{O}$ ' genotypes) and medium (' $\mathrm{T}$ ' genotype) prolificacy. Despite different average ovulation rates of $3.05,1.85,1.18$ and 1.37 for Booroola, ' $T$ ', ' $O$ ' and ' $C$ ' ewes, respectively, there were no consistent differences in the time of the LH discharge which occurred on average $4.5 \mathrm{~h}$ after the onset of oestrus. Time of ovulation was studied, in two experiments involving $\mathbf{4 3 0}$ Booroola, ' $T$ ', ' $O$ ' and ' $C$ ' ewes, by laparoscopic ovarian examination of subsamples of ewes at $20,24,28$ or $32 \mathrm{~h}$ after onset of oestrus. Ovulation occurred significantly $(P<$ 0.001 ) earlier $(7.5 \mathrm{~h})$ in Booroola ewes than in those of the other genotypes.
\end{abstract}

\section{Introduction}

Hormonal studies of prolific sheep breeds have failed to show consistent relationships between gonadotrophin concentrations and the number of ovulations. Comparisons of breeds and genotypes of low and high prolificacy have, however, consistently shown differences in the timing of the preovulatory $\mathrm{LH}$ discharge relative to the onset of oestrus, ewes with high ovulation rates having a significantly longer interval (Thimonier \& Pelletier, 1971; Land, Pelletier, Thimonier \& Mauléon, 1973; Wheaton, Raabe \& Burrill, 1977; Bindon, Blanc, Pelletier, Terqui \& Thimonier, 1979; Quirke, Hanrahan \& Gosling, 1979; Cahill et al., 1981). In comparisons between ewe lambs and adult ewes (Quirke et al., 1981), adults had a longer interval between the onset of oestrus and the LH discharge. Although the physiological significance of this phenomenon is unknown it seemed worthy of additional study on a within-breed basis. The present investigations therefore compare the preovulatory LH characteristics in Australia's highly prolific sheep breed, the Booroola Merino, with control Merinos of low prolificacy, and include studies of the time of ovulation in sheep of these genotypes.

\section{Materials and Methods}

Animals. The Merino genotypes examined were random-bred control (C) Merinos and the ' $O$ ', ' $T$ ' and Booroola selection flocks described by Turner (1978). The ' $T$ ' and ' $O$ ' flocks are derived from the same base population and have been selected for and against litter size at birth since 1954. The Booroola Merino originated on a private farm and the CSIRO flock is based on samples of the Booroola ewes and rams obtained in 1958 and 1960. Since that time the flock has also been selected for litter size at birth. All 4 flocks have been maintained in the same environment and subjected to the same management on the same property at Armidale since 1964. Average liveweights for ewes

* Present address: Laboratoire de Physiologie, INRA, Nouzilly, France. 
of mixed age are $40 \cdot 6 \pm 0 \cdot 3,40 \cdot 6 \pm 0 \cdot 5,41 \cdot 5 \pm 0 \cdot 4$ and $39 \cdot 7 \pm 0 \cdot 3 \mathrm{~kg}$ for ' $\mathrm{C}$ ', ' $\mathrm{O}$ ', ' $\mathrm{T}$ ' and ' $\mathrm{B}$ ' flocks respectively: these are not significantly different (Bindon, Piper \& Evans, 1982). The relative levels of prolificacy of these flocks can be assessed from their average ovulation rates based on ewes of mixed age studied during 1970-1980. The mean ovulation rates (range in brackets) recorded were $1.23(1-2), 1.13(1-2), 1.86(1-4)$ and $3.56(1-11)$ for the ' $C$ ', ' $O$ ', ' $T$ ' and ' $B$ ' flocks respectively.

The ' $\mathrm{C}$ ' and ' $\mathrm{O}$ ' flocks thus have reproductive rates representative of average commercial Merinos. The ' $T$ ' flock is significantly more prolific while the Booroola has litter size and ovulation rates equivalent to the Romanov, Finnsheep and D'man breeds which all have exceptional prolificacy.

Measurement of preovulatory $L H$ characteristics. These data are derived from four separate experiments, each carried out in May/June of different years on ewes aged 2-8 years from genotypes and numbers of ewes as described in Table 1. All experiments involved normal oestrus, studied at the second cycle after synchronization with intravaginal progestagen pessaries (Repromap: Upjohn Australia Ltd). The onset of oestrus was detected by inspection of ewes every 2 $\mathrm{h}$ or every $4 \mathrm{~h}$ (Exp. 1 only) for oestrous crayon service marks made by vasectomized rams (at least 8 rams $/ 100$ ewes). Inspections began on the 19 th day after removal of the pessaries. In between inspections the animals remained on pasture. In Exp. 1 the ewes remained with rams throughout oestrus and had the opportunity for repeated copulation. In Exps 2, 3 and 4 ewes were separated from rams after the onset of oestrus but remained in close proximity. Ovulation rates were not measured in Exp. 1. In Exps 2-4 ovulation rates were assessed by laparoscopy 3-7 days after oestrus.

Jugular venous blood samples were withdrawn from the onset of oestrus at intervals of $4 \mathrm{~h}$ for the duration of oestrus in Exp. 1 and at 2-h intervals for 24, 12 and $36 \mathrm{~h}$ in Exps 2, 3 and 4 respectively. Plasma samples were assayed for $\mathrm{LH}$ as described below and the following characteristics were calculated for each animal where appropriate: Interval $(I ; h)=$ hours from onset of oestrus to the start of the LH discharge defined arbitrarily here as the point when LH concentration exceeded $4 \mathrm{ng} / \mathrm{ml}$. Since the same arbitrary point was used for all genotypes being compared, it does not bias the contrasts being made between genotypes for this LH characteristic; Peak LH $(\mathrm{P} ; \mathrm{ng} / \mathrm{ml})=$ maximum LH concentration recorded; Duration $(\mathrm{D} ; \mathrm{h})=$ hours from start to end of LH discharge; Area $(\mathrm{A} ; \mathrm{mg})=$ area under the LH discharge curve estimated by weight of standardized graphs of the discharge.

Measurement of time of ovulation. In Exp. 5, 216 ewes aged 2-10 years were examined (102 ' $\mathrm{O}$ ', 60 ' $T$ ', 32 ' $B$ ' and 22 ' $C$ ' ewes). In Exp. 6 there were 214 ewes aged 2-8 years, comprising 93 ' $T$ ', 40 ' $B$ ' and 81 ' $C$ ' ewes. The ' $O$ ' genotype was therefore studied in one year only. In both experiments ewes were assigned at random within age and genotype to groups for ovarian examination at 20,24, 28 or $32 \mathrm{~h}$ after onset of oestrus. Each animal was examined at one time only during oestrus. Ovulation was assessed from ovarian examinations by laparoscopy as described by Thimonier \& Mauléon (1969). The operation was repeated 7 days later to confirm that ovulation did subsequently occur and to assess the number of ovulations. Ewes that had not ovulated (10 in the two experiments) at the Day 7 laparoscopy were eliminated from the data.

Hormone assay. Concentrations of LH were measured in duplicate $300 \mu \mathrm{l}$ plasma samples by a solid-phase radioimmunoassay, the validation details for which have been described by Cummins, O'Shea, Bindon, Lee \& Findlay (1983), and Gidley-Baird \& Bindon (1976). Within experiments all samples were processed in the one assay. In the 4 separate assays the limit of sensitivity did not exceed $0.66 \mathrm{ng} / \mathrm{ml}$ plasma using NIH-LH-S16 as standard. Within-assay coefficient of variation for reference samples ranged from 5.6 to $9 \%$ for a reference ovine plasma containing $5 \mathrm{ng} / \mathrm{ml}$ and 11 to $13 \%$ for samples containing $15 \mathrm{ng} / \mathrm{ml}$. Results are expressed as $\mathrm{ng}$ NIH-LH-S16/ml plasma.

Statistical procedures. Preovulatory LH discharge characteristics of sheep were compared by Student's $t$ tests after preliminary tests of differences due to age of ewe. Time of ovulation data were compared by $\chi^{2}$ tests of independence. 


\section{Results}

\section{Preovulatory $\mathrm{LH}$ characteristics}

Onset of oestrus and LH discharge in Exp. 1 were estimated with less precision in this than other experiments, because observations were made every $4 \mathrm{~h}$. As shown in Table 1 the 'B', ' $T$ ' and ' $O$ ' ewes had intervals (I) between onset of oestrus and the LH discharge that were not significantly different. Peak $L H$ concentrations were not significantly different between ' $O$ ' and ' $B$ ' ewes, but ' $T$ ' ewes had significantly $(P<0.05)$ higher peak values.

In Exps $2-4$ the mean I values varied between experiments from 2.3 to $6.7 \mathrm{~h}$, but within experiments Booroola and other genotypes were not significantly different, despite consistent differences in ovulation rate (Table 1). This was also true for the other LH characteristics studied, with the possible exception of the peak LH concentration which was significantly larger $(P<0.05)$ in ' $T$ ' than ' $C$ ' or Booroola genotypes in Exp. 4. With a 2-h sampling frequency the peak LH values could only be regarded as approximate, however.

\section{Time of ovulation}

The results from Exps 5 and 6 have been pooled for presentation in Text-fig. 1 which shows the percentage of ewes ovulating at intervals after the onset of oestrus. At all intervals examined there were substantially higher proportions of Booroola ewes that had ovulated than of ' $O$ ', ' $T$ ' or ' $C$ ' ewes. Even allowing for the smaller numbers of ' $\mathrm{B}$ ' ewes in the study it must be concluded that ovulation occurs earlier in this genotype. If the point at which $50 \%$ of ewes have ovulated is estimated by probit analysis the Booroola ewes were about $7.5 \mathrm{~h}$ earlier than the average of the other 3 genotypes. At $32 \mathrm{~h}$ after onset of oestrus only $63 \%$ of the pooled ' $O$ ', ' $T$ ' and ' $C$ ' genotypes had ovulated. To test the significance of these different ovulatory patterns the $\chi^{2}$ test of independence was applied to the overall proportion of ewes ovulated for each genotype for the 4 times of endoscopy: i.e. $34,21,23$ and $58 \%$ for the ' $C$ ', ' $O$ ', ' $T$ ' and ' $B$ ' flocks respectively $\left(\chi^{2}(3)=\right.$ 33.84; $P<0.001$ ).

Within the Booroola flock there was a suggestion that the ewes that ovulated early had higher ovulation rates than ewes of the same age that had not ovulated. For example, with Booroola ewes

Table 1. Preovulatory LH characteristics and ovulation rate in control (C), 'O', ' $T$ ' and Booroola (B) Merinos in 4 separate experiments

\begin{tabular}{|c|c|c|c|c|c|c|c|c|}
\hline \multirow[b]{2}{*}{ Exp. } & \multirow[b]{2}{*}{ Genotype } & \multirow[b]{2}{*}{$\begin{array}{c}\text { Age } \\
\text { (years) }\end{array}$} & \multirow{2}{*}{$\begin{array}{l}\text { No. } \\
\text { of } \\
\text { ewes }\end{array}$} & \multirow[b]{2}{*}{$\begin{array}{l}\text { Ovulation } \\
\text { rate }\end{array}$} & \multicolumn{4}{|c|}{ LH characteristics* } \\
\hline & & & & & $\begin{array}{c}\text { I } \\
\text { (h) }\end{array}$ & $\underset{\text { (ng/ml) }}{P}$ & $\underset{\text { (h) }}{D}$ & $\underset{(\mathrm{mg})}{\mathrm{A}}$ \\
\hline 1 & $\begin{array}{l}\text { B } \\
\text { T } \\
\text { O }\end{array}$ & $\begin{array}{l}2-7 \\
2-7 \\
2-7\end{array}$ & $\begin{array}{r}11 \\
16 \\
7\end{array}$ & $\begin{array}{l}- \\
-\end{array}$ & $\begin{array}{l}5.09 \pm 1 \cdot 1 \\
7.50 \pm 1.5 \\
4.57 \pm 1.8\end{array}$ & $\begin{array}{r}85 \pm 13 \\
160 \pm 20 \\
94 \pm 26\end{array}$ & - & $\overline{-}$ \\
\hline 2 & $\begin{array}{l}\text { B } \\
\text { O }\end{array}$ & $\begin{array}{l}4-8 \\
4-8\end{array}$ & $\begin{array}{l}28 \\
12\end{array}$ & $\begin{array}{l}2.68 \pm 0 \cdot 15 \\
1 \cdot 18 \pm 0 \cdot 12\end{array}$ & $\begin{array}{l}4.36 \pm 0.64 \\
4.83 \pm 0.96\end{array}$ & $\begin{array}{l}132 \pm 13 \\
141 \pm 22\end{array}$ & $\begin{array}{l}18 \cdot 3 \pm 0 \cdot 6 \\
17 \cdot 3 \pm 1 \cdot 1\end{array}$ & $\begin{array}{l}268 \pm 24 \\
309 \pm 50\end{array}$ \\
\hline 3 & $\begin{array}{l}\text { B } \\
\text { C }\end{array}$ & $\stackrel{5}{5-8}$ & $\begin{array}{l}11 \\
12\end{array}$ & $\begin{array}{l}3.91 \pm 0.46 \\
1.25 \pm 0.13\end{array}$ & $\begin{array}{l}4.18 \pm 0.99 \\
6.67 \pm 1.52\end{array}$ & $\begin{array}{l}70 \pm 3 \\
72 \pm 5\end{array}$ & $\begin{array}{r}9.8 \pm 0.8 \\
10.5 \pm 0.8\end{array}$ & $\begin{array}{l}132 \pm 12 \\
139 \pm 13\end{array}$ \\
\hline 4 & $\begin{array}{l}\text { B } \\
\text { T } \\
\text { C }\end{array}$ & $\begin{array}{l}2-8 \\
2-8 \\
2-8\end{array}$ & $\begin{array}{l}11 \\
13 \\
12\end{array}$ & $\begin{array}{l}2.55 \pm 0.43 \\
1.85 \pm 0.15 \\
1.50 \pm 0.15\end{array}$ & $\begin{array}{l}2.55 \pm 0.67 \\
2.46 \pm 0.56 \\
2.33 \pm 0.59\end{array}$ & $\begin{array}{l}29 \pm 6 \\
62 \pm 7 \\
34 \pm 7\end{array}$ & - & $\begin{array}{l}- \\
-\end{array}$ \\
\hline
\end{tabular}

Values are mean \pm s.e.m.

* I, interval from onset of oestrus to start of LH discharge; P, maximum LH conc. recorded; D, duration from start to end of LH discharge; A, area under LH discharge curve expressed as weight of standardized graph of discharge. 


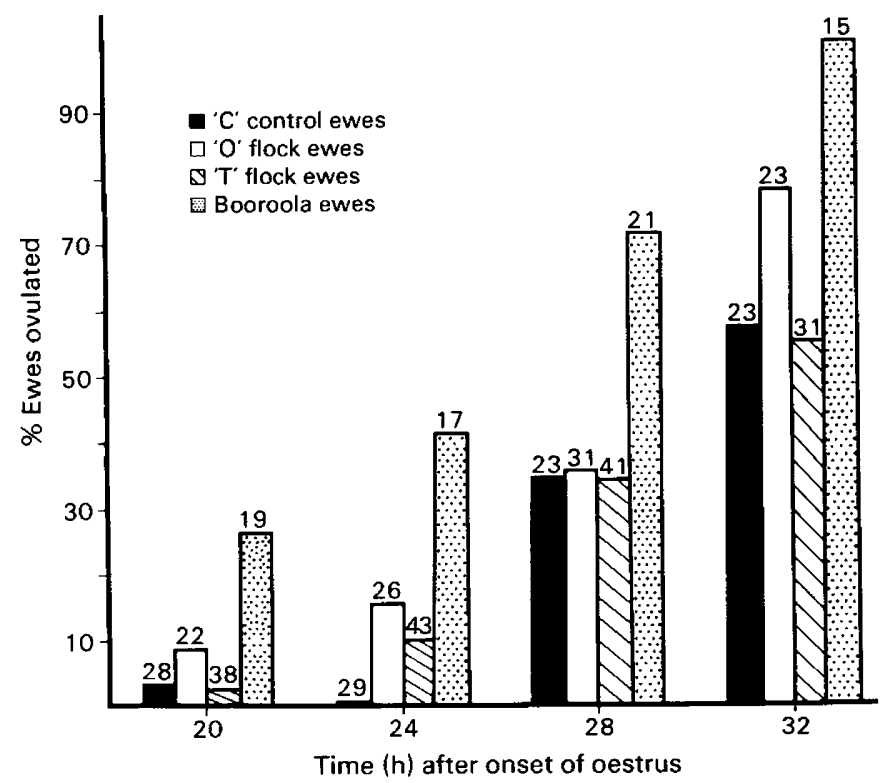

Text-fig. 1. The percentage of ewes that had ovulated at various intervals after onset of oestrus. Separate samples of ewes of each genotype were examined at each interval, the numbers being shown above each histogram.

aged 1.5 years examined at +20 and $+24 \mathrm{~h}$ after onset of oestrus there were 17 that had not ovulated and 8 that had. These two sub-classes were subsequently (i.e. 7 days later) shown to have mean ovulation rates of $2.59 \pm 0.24$ and $3.64 \pm 0.34$ respectively $(t=2.27$, d.f. $=23 ; P<0.05)$.

\section{Discussion}

From the seven separate investigations of the LH discharge in prolific sheep cited in the 'Introduction' the expectation was that breeds or phenotypes with high ovulation rates should have a longer interval between the onset of oestrus and the LH discharge than ewes with low ovulation rate. From Table 1 it is clear that this was not confirmed for the prolific Booroola Merino ewe. When the preovulatory LH discharge was compared in the Booroola and other Merino genotypes on 4 separate occasions there was considerable between-experiment variation in the absolute $\mathrm{LH}$ values recorded. This may be attributed to year effects, to the different samples and ages of animals studied and to between-assay variation. However, within any one of the 4 experiments there was no evidence that Booroola ewes had a longer interval between onset of oestrus and the LH discharge. From these data it seems doubtful whether the timing of the LH discharge plays any significant part in the regulatory mechanisms controlling ovulation rate in these genotypes.

Appropriate comparisons amongst prolific breeds have not been made in the one environment and this may resolve the apparently anomalous results for the Booroola. Such comparisons are not presently possible since the Booroola exists only in Australia and New Zealand, and is the only prolific breed in these countries.

Time of ovulation has not previously been studied in comparisons of normal and prolific sheep breeds. It is important, in discussing this phenomenon, to emphasize that precise ovulation time may not be determined for each animal: repeated laparoscopy, even under barbiturate anaesthesia is prohibitively traumatic for the animal and in any case the stress of the procedure or the 
anaesthesia may delay ovulation. Therefore, ovulation time can only be reasonably compared by examination of a single sub-sample of ewes at a single time after onset of oestrus. In the present work this involved a total of 430 ewes from the 4 genotypes being compared. From Text-fig. 1 it is evident that, on average, Booroola ewes ovulated earlier than the other genotypes and probit analysis suggests the magnitude of the difference is approximately $7.5 \mathrm{~h}$. This difference does not seem to be simply a function of multiple ovulation, since the ' $T$ ' flock, with approximately $80 \%$ multiple ovulations had a similar ovulation time pattern to the control Merinos. However, it is equally clear from Table 1 that the LH discharge occurred at the same time in Booroola ewes as in the other genotypes. We conclude that the interval between the LH surge and ovulation is shorter for the Booroola and that the preovulatory follicle responds more quickly to the surge of LH. These results are at variance with previous studies (e.g. Cumming et al., 1973) suggesting that the interval between the LH discharge and ovulation is relatively constant, and with one report (Whyman, Johnson, Knight \& Moore, 1979) in which it was shown that PMSG-treated ewes ovulated about 24 $h$ after onset of oestrus. The latter study, however, involved repeated endoscopy of the same group of ewes which comprised animals of 6 breeds and unknown age; it may not therefore be directly comparable with the present work.

A further point of interest from Text-fig. 1 is that at $32 \mathrm{~h}$ after onset of oestrus a substantial $(37 \%)$ proportion of what could be regarded as normal Merinos had not yet ovulated. This may be a source of infertility when ewes are inseminated, naturally or artificially, early in oestrus.

We thank M. Cheers, Y. Curtis and R. Nethery for technical assistance. The work was supported by the Australian Meat Research Committee and the Australian Wool Corporation.

\section{References}

Bindon, B.M., Blanc, M.R., Pelletier, J., Terqui, M. \& Thimonier, J. (1979) Periovulatory gonadotrophin and ovarian steroid patterns in sheep breeds with differing fecundity. J. Reprod. Fert. 55, 15-25.

Bindon, B.M., Piper, L.R. \& Evans, R. (1982) Reproductive biology of the Booroola Merino. In The Booroola Merino, pp. 21-23. Eds L. R. Piper, B. M. Bindon \& R. D. Nethery. CSIRO Publications, Melbourne.

Cahill, L.P., Saumande, J., Ravault, J.P., Blanc, M., Thimonier, J., Mariana, J. \& Mauléon, P. (1981) Hormonal and follicular relationships in ewes of high and low ovulation rates. J. Reprod. Fert. 62, 141-150.

Cumming, I.A., Buckmaster, J.M., de B. Blockey, M.A., Goding, J.R., Winfield, C.G. \& Baxter, R.W. (1973) Constancy of interval between luteinizing hormone release and ovulation in the ewe. Biol. Reprod. 9, 24 29.

Cummins, L.J., O'Shea, T., Bindon, B.M., Lee, V.W.K. \& Findlay, J.K. (1983) Ovarian inhibin content and sensitivity to inhibin in Booroola and control strain Merino ewes. J. Reprod. Fert. 67, 1-7.

Gidley-Baird, A.A. \& Bindon, B.M. (1976) Solid phase assay for luteinizing hormone in mouse plasma. Aust. J. biol. Sci. 29, 105-116.

Land, R.B., Pelletier, J., Thimonier, J. \& Mauléon, P. (1973) A quantitative study of genetic differences in the incidence of oestrus, ovulation and plasma luteinizing hormone concentration in the sheep. $J$. Endocr. 58, 305-317.
Quirke, J.F., Hanrahan, J.P. \& Gosling, J.P. (1979) Plasma progesterone levels throughout the oestrous cycle and release of $\mathrm{LH}$ at oestrus in sheep with different ovulation rates. J. Reprod. Fert. 55, 37-44.

Quirke, J.F., Hanrahan, J.P. \& Gosling, J.P. (1981) Duration of oestrus, ovulation rate, time of ovulation and plasma $\mathrm{LH}$, total oestrogen and progesterone in Galway adult ewes and ewe lambs. J. Reprod. Fert. 61, 265-272.

Thimonier, J. \& Mauléon, P. (1969) Variations saisonnieres du comportement d'oestrus et des activites ovarienne et hypophysaire chez les ovins. Annls Biol. anim. Biochim. Biophys. 9, 233-250.

Thimonier, J. \& Pelletier, J. (1971) Difference genetique dans le decharge ovulante (LH) chez la brebis de race Ile-de-France; relations avec le nombre d'ovulations. Annls Biol. anim. Biochim. Biophys. 11, 559-567.

Tumer, H.N. (1978) Selection for reproduction rate in Australian Merino sheep: direct responses. Aust. J. agric. Res. 29, 327-350.

Wheaton, J.E., Raabe, T.I. \& Burrill, M.J. (1977) Characteristics of the ovulatory release of luteinizing hormone in Finn, Finn $\times$ Suffolk and Suffolk ewes. J. Endocr. 75, 449-450.

Whyman, D., Johnson, D.L., Knight, T.W. \& Moore, R.W. (1979) Intervals between multiple ovulations in PMSG-treated and untreated ewes and the relationship between ovulation and oestrus. J. Reprod. Fert. $55,481-488$.

Received 31 October 1983 